\title{
Pastoral care and narrative: Towards a narrative pastoral care approach in intercultural communities
}

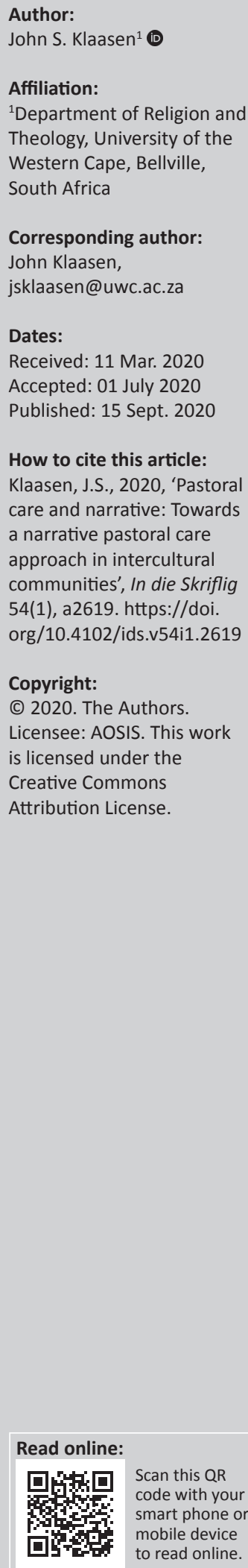

Narrative therapy, or narrative pastoral care, is one of the approaches of the last three decades that has attempted to address care for our current fluid communities. Stories and narratives play an important role in the meaning making of personhood and identity. Narratives and stories are becoming more used and recognised as an indispensable part of the healing of vulnerable persons within Psychology, Literature, Sociology and Theology. This contribution is an attempt to add to the growing scholarship of story and narrative approaches in Pastoral Care and Counselling by providing markers for a developing model of pastoral care within intercultural contexts. I will give a brief overview of pastoral care within four different contexts. The narrative approaches of Muller and Ganzevoort will be analysed and critically engaged because of their extensive and elaborative research of narrative for pastoral care and counselling. After a brief overview and critique of Muller and Ganzevoort, I will identify additional markers for narrative pastoral care in intercultural contexts.

Keywords: narrative; pastoral care; interculturality; Muller; Ganzevoort; meaning making; healing.

\section{Introduction}

Pastoral care needs to take seriously the intercultural contexts of post-globalised and universalised societies. Identities of individuals, communities, societies and nations are changing at an unprecedented rate because of mass migration, the ease of mobility and the diversity of communities, including visual communities. Traditional forms of care for the postmodern person needs critical engagement for its relevance and effectiveness. Narrative pastoral care is one of the approaches of the last three decades that has attempted to address care for our current fluid communities. The stories and narratives of persons in need plays an important role in the meaning making of personhood. Stories are largely absent or neglected as a significant substantive contributor in the pastoral process and functions, except for isolated voices in the wilderness. Narrative or story approaches have a diverse use in disciplines such as Psychology, Sociology, Medicine, Literature and Cultural Studies. Story and narrative are often used interchangeably. According to Riley and Hawe (2005), the main difference is the following:

$[W]$ here the primary data ends and where the analysis of the data begins. Frank (2000) points out that people tell stories, but narratives come from the analysis of stories. Therefore, the researcher's role is to interpret the stories in order to analyse the underlying narrative that the storytellers may not be able to give voice to themselves. (p. 227)

The functions of narrative vary from constructing individual and communal identity, creating agency, mobilising people for transformation and change, making sense of experiences, and critically engaging normativity (Barcelos \& Gubrium 2014:2). To place this article in context, I will give a brief overview of pastoral care within four different contexts. Within the African pastoral care discourse, Müller is one of the most prominent theologians who uses narrative as a tool within pastoral care. Within Western pastoral care, Ganzevoort has been one of the most influential voices within the discourse of narrative and pastoral care. After a brief overview and critique of Müller and Ganzevoort, I will identify additional markers for narrative pastoral care in intercultural contexts.

\section{Pastoral care: A brief overview}

What role does narratives play in pastoral care processes in intercultural communities? Within ever-evolving communities from monocultural experience to multi-cultural contexts, pastoral care models such as Western individualistic, rationalistic, emotional-expressive approaches with the goal of satisfying the ego or self (e.g. Halmos 1965; Holifield 1983; Lambourne 1974; 
Wilson 1988 all quoted in Lartey 2006:50) have come under renewed critique for their consumerist and materialistic nature. Asian approaches to pastoral care have also come under considerable scrutiny in recent years. Despite the rich religious and cultural pluralistic societies and the emphasis on 'cosmic unity and cohesiveness', pastoral care has largely remained a personal phenomenon. Lartey (2006:57) rightly asserts that 'Asian emphasis on the communal within the context of religious pluralism raises important questions for pastoral therapeutic practice in general and for pastoral theology in Asia particularly'. Relationality is central to care within African perspectives of pastoral care. The interaction between and among humans, between humans and the cosmos, and between living and non-living beings is the tool to assess the equilibrium of meaning making and freedom of persons. Pastoral care is the process to restore relationships. African pastoral care attempts to keep in tension indigenous cultural practices and religion with Christian rituals, symbols and beliefs in the healing process. While African pastoral care takes the local cultural practices as a more significant phenomenon in pastoral care than the Western and Asian approaches, the unconscious is generally neglected or suppressed by an African worldview and single biblical worldview (Acolatse 2014:173). Pastoral care in Latin America has two dominant paradigms - Protestant (sometimes referred to as Evangelical) and Catholic pastoral care. Within the latter, the pueblo [people], particularly the poor, are the form of agency. The former is situated within globalisation (individualistic approach,) while the latter is embedded in Latin American liberation theology. Pastoral care is institutional and communal, and the widely accepted as Acolatse (2014) indicates:

$[P]$ opular pastoral care emerged and functions with the poor as they seek their liberation. Rejecting hierarchical, top-down approaches to pastoral care, Latin American theologians and people have embraced Basic Christian Communities (BCC's) as the locus through which care is mediated. (p. 173)

The marks of care are trust, listening to the poor and encouraging them to tell their story (Lartey 2006:69).

In a previous publication, I identified the following shortcomings of conventional pastoral care models: Firstly, reality is limited to interpreted experience. The focus is on problems and how to solve problems. In the pastoral counselling process, the tendency is to emphasise the professional skills and abilities of the giver. Secondly, the pragmatic action-oriented process dominates the more visionary, artistic, and philosophical identity formation. Thirdly, such approaches do not address imbalanced power relations between the cared for and the carer. Fourthly, communication is structuralist and implies rigidity (Klaasen 2018a:3).

Within the Latin-American model of pastoral care, the story of the poor is placed within the broader narrative of institutions, social entities and government. The danger exists that the story of the poor is encapsulated by the more powerful narratives of the community, society, culture, government and other institutions. How is the story of those in need weaved as a tool of healing amidst the dominant narratives of the powerful, professional and societal? Ganzevoort gives a more prominent position to story or narrative within pastoral care than the traditional forms of pastoral care, including liberation theology's popular pastoral care.

\section{Ganzevoort's approach to narrative}

Ganzevoort was one of the first practical theologians to investigate stories and narratives for pastoral care. As far back as 1993, Ganzevoort asserts that:

A story is not just a way of conveying information, it is a way of
interpreting facts. Every story attributes a certain meaning to the
events it relates. That is why story-telling is an important aspect
of life, because human life can be seen as a continuous process
of interpreting and ordering the world in images and stories.
(p. 278)

Ganzevoort further claims that when experiences are put in a structure or sequence (plots), disconnected parts of life are put in a process of interpretations. It is possible that events are first experienced at a subconscious level and after interpretation experiences are placed within a narrative. This process of interpretation includes language, identity and continuity. 'We therefore define life-stories as narrative patterns of interpretations whereby we seek to discover the sense, meaning and value of life of the events occurring in it' (Ganzevoort 1993:278).

Within the pastoral care setting, four basic characteristics of narrative are identified. The plot refers to a recognisable continuous decorative design that connects events. The setting refers to the pattern that is formed by political, social, economic and cultural factors. Character refers to the personal touch that is represented by symbols, metaphors and rituals that influence the relationships of the person. And lastly, tone describes the overarching emotional setting of the story (Ganzevoort 1993:285-286). These four characteristics are present in every narrative, but the degree of importance could differ.

Narrative and pastoral care is hermeneutical rather than facts based only. The interpretation of experiences is more important than the interpretative rules that make up the experiences. Ganzevoort shifts the movement away from rule-oriented hermeneutics to the understanding and analysis of the process of the interpretation. He notes that since the Enlightenment, three philosophers-Schleiermacher, Dilthey and Gadamer - have highlighted this shift. They were more interested in understanding the unfolding of the interpretation of facts within personal settings and time reference. Hermeneutics is defined as the methodology for arriving at an understanding of written texts held to be meaningful at a personal level'. Within pastoral care, practical theologians have developed different methods of hermeneutics. Anton Boisen used the notion of the person's 
life as 'a living document' which can be analysed in a similar way to texts of the Bible (1993:289).

What is the role of stories in pastoral care and, specifically in the process of pastoral care? Ganzevoort demonstrates the role of stories with the notion of 'storyscapes'. According to Ganzevoort (2017), life-stories as personal stories when interlinked with personal identity and personal choice, forms the personal narrative landscape. Storyscapes 'can be seen as the surrounding landscape of interconnected stories with which we inevitably interact'. Cense and Ganzevoort (2018) claim that:

[A] storyscape refers to the combination of repertoires and normativity provided by the social and cultural context and the narrative audience to which the narrator responds ... it asks which narrative is presented to an individual and how she or he constructs a life narrative to respond to the world. (p. 572)

The counsellee responds to a socially constructed reality that is presented as a conglomerate of stories. Reality is those episodes that are repeated and taken as the norm. When constructing a life story, the counsellee takes cognisance of the narratives of the dominant powerful phenomena such as culture, community, observers and the counsellor. It is to these traditional mega-stories that the counsellee responds. She or he constructs a narrative that is meaning making and life giving, and that forms part of the cluster of stories.

The response of the counsellee is in the form of negotiation. Instead of competing with existing stories, the counsellee finds ways of connecting and disconnecting with the stories in such a way that their story forms part of the pattern of narratives of the community or society. In this regard Cense and Ganzevoort (2018) remarks:

First, against the backdrop of the storyscape, individuals develop a life story by reflecting on their embodied experiences and the perceived 'reality' around them ('emplotment'). In this 'referential negotiation' people turn material reality into narrative. The next negotiation is the 'performative negotiation', in which people turn narrative into material and behavioural reality and facilitate new experiences and changes in reality, interacting with their narrative audience ('enactment'). (p. 572)

In this way, the counsellee finds meaning in their circumstances - that does not confound them or thwart healing - but transforms their circumstances into life giving opportunities. Negotiation results in giving meaning to experiences and shaping life giving relationships with different audiences, whether the counsellor, family, congregation, community, a colleague or friend.

Ganzevoort rightly follows the shift from doctrinal and ideational approaches to experience. Unlike Boisen, Hiltner and James (in the North American context of pastoral care), who shifted the focus to human experience, Britain's modern secular theologians such as Robinson, encompass a more deliberate use of experience. They use the hermeneutical lens in liberation theology (including women's theology, black theology, feminist theology, queer theology and gay theology), and Ganzevoort speaks about embodied experience (Cense \& Ganzevoort 2018:572). Experience refers to the lived experience of the affected person(s). Embodied experiences refer to the tangible visible action or movement of the person in need. Ganzevoort's negotiation changes the experiences of the person from a negative one into a life giving, meaning making experience.

Experience (praxis) should not be isolated from reason (theory). Within the discipline of practical theology, the scholarships of Tracy (the distinction but not separation of theory and practice), Forrester (the two are integrally related), Heitink (circular) and Browning (interpenetrated) are worth noting (Klaasen 2018b:7). He refers to reflected experience which, 'as narrated by the cared for produces a kind of knowledge that informs care' (Klaasen 2018b:7). Reflected experience is schematically presented as practice, theory, practice and theory. Drawing from Browning's three-pronged approach of practice, theory and practice, theory is introduced as a fourth component, that is, reflection on the transformed experience (Klaasen 2018b:7). In terms of embodied experience, it means that the story that the counsellee chooses to give meaning to her or his experience, is also under further serious thought and reflection.

Ganzevoort's narrative approach assumes that society is monocultural, and for that reason the cared for has the less complicated task of placing her or his story alongside the narrative of culture, politics and society. Culture has been complicated by globalisation and universalisation, and now the plurality of peoples and nations. People connect easier today than during the pre-technological era and the result is increased access to other forms of cultures, practices and customs. In Western societies such as the Netherlands immigration has resulted in intercultural societies. In the same way, post-apartheid South Africa is not as mono- or multicultural as in the apartheid era. With the easy commuting between spaces and the influx of people from other parts of Africa, South Africa is best described as intercultural. Lartey (2004) describes interculturality as:

$[T]$ he complexity involved in the interactions between people who have been and are being shaped and influenced by different cultures. It takes seriously the different expressions originating in different cultures but the proceeds by attempting to make possible a multi-perspectival examination of whatever issue is at stake. (p. 32)

Yet, Ganzevoort does not discard significance as an imperative aspect of meaning making. At least within loss and bereavement counselling, narrative brings to the surface the ambiguities of reason and cognition. In an extensive study among parents who lost a child, Ganzevoort's findings (Ganzevoort \& Falkenburg 2012) include:

The narrative approach suggested that it is significance and not cognitive mastery (Wheelere 2001) or sense making (Keesee et al. 2008; Lichtenthal et al. 2010; Neimeyer et al. 2006) that predominates in the search for meaning, though the latter certainly features in the stories. (p. 2001) 
Implicit in the assumption of significance for meaning making is the underlying assertion that the storyteller gives meaning to experiences within the context of the audience. Within intercultural settings, communities and congregations, the storyteller considers the interactionist, complex, dynamic, mutual enriching phenomena of difference without separation. Different rituals, symbols, customs and actions impact meaning making. The cared for tell their story in a way that it makes sense to them. However, the audience is one of the aspects that can unlock ambiguities which can add to the more obvious fundamentals. The fundamentals, coupled with the ambiguities, contribute to the reconstruction of a meaningful life amidst conflicting and distorted narratives.

Reconstruction of a meaningful life does not have to discard reason, providing that reason is not the only determination for meaning making and life-giving pastoral care. Narrative pastoral care is not irrational or a-rational, but abstract reason minimises the importance of factors such as tradition, history, symbols, metaphors and non-observables, including divine, sacred and transcended realities. Pastoral care in intercultural settings is effective if it concedes to the tension between rational and non-rational determinants. Instead of disjoining reason and significance of meaning, different forms of reason such as embedded reason (Klaasen) or practical reason (Browning) are more significant, because it takes experiences as an imperative phenomenon in navigating transformed stories.

Reason and experience are also in tension from an embedded reason perspective when one considers that experience is not limited to actual or lived experience. Experience in this sense refers to observable experience or measured experiences. The other perspective is that experience refers to spiritual or envisioned experience. In other words, experience is more than what we observe. Envisioned experience and spiritual experience are given meaning within the telling of narratives. In their study, Ganzevoort and Falkenburg (2012) observe:

Spiritual experiences are part of the ongoing narratives of parents who lost their child. Their main function is to embody and imbed the continuing bond with their child and with transcendence. In this way they further the continuation of their life story. (p. 199)

Storytelling is not an end in itself. Storytelling leads to healing, to meaning making, to restoration, to restored relationships and to reconciliation. Storytelling provides both the structure and process for meaning making of embedded experiences. People going through difficult times and hardships find themselves entangled by narratives that thwart development in favour of vulnerability and dependency. Storytelling puts the agency back with the counsellee to take responsibility for discontinuity with false and distorted narratives and perceptions of disempowering meaning and continuity with plots of the story that empowers the counsellee to take responsibility for their own story.
The negative event takes on a new meaning that weaved its way through the dominant narratives and healing is equivalent with different lenses of interpretation. In a study among homosexual persons from different cultural groups in the Netherlands, two types of agency were distinguished: Firstly, subtle agency, which refers to the avoidance to come out with explicit statements about one's condition as verbalised by Cense and Ganzevoort (2017):

Quiet diplomacy works better than the (Dutch) shouting from the rooftops. Many youths give positive cultural labelling to more subtle strategies, as these are seen as showing more respect and loyalty towards the cultural community. (p. 664)

Secondly, public agency is engaging the society, media, communities, culture, religions and governments directly and openly. The results of this form of agency can cause public awareness, social action, policy reforming and, more importantly, confront metanarratives such as culture and ethnicity (Cense \& Ganzevoort 2017:666).

These forms of agency ask questions about the relationship between the counsellee and the other narratives within the storyscape. Storytelling should address the power relations between the counsellee and the counsellor and the audience who represent the different dominant narratives. When power relations are considered as a constructed part of pastoral care, then the space and time of the story enactment has a bearing on the substance of the story. Although the power of the storyteller lies in the ability to transform their story into a storyscape of their own through negotiation, the question of whose story remains important within intercultural pastoral care.

Cense (2019) asserts that 'the concepts of power through and power over' precedes the discussion about the commonly accepted dualism of agency and structure. In a comprehensive discussion about agency and structure, she points out that agency can be understood as the ability to act within a given social structure, whereas the opposite is also true. Agency can be understood as liberation from structures. Agency is also perceived as freedom to choose. Agency can also be the ability to keep the tension between different social actors and social aspects. It is perhaps Mahmood's perception of the agency-structure debate that is most illuminating. Mahmood concludes that agency is not restricted to the ability to change - but resistance, endurance and persistence are equally part of agency. This is an important aspect of pastoral care, because the counsellee is usually accepted as the one in need and whose healing is measured by positive change, but also the ability to resist domination and distorted relationships that cause subordination and bondage (Cense 2019:15-16).

\section{Müller, transversality and postfoundationalism}

Müller is one of the most respected practical theologians who made a significant contribution to narrative practical theology and pastoral care. Müller's work on narrative 
theraphy goes back as far as 1990. Müller's narrative paradigm of therapy (2011:1) started with four core elements. The first element is that life is a journey. Drawing from Richard Niebuhr's perspective of life as 'inner and outer history', Müller (1998) assumes that the past and future form part of the present identity of a person:

To be self is to live toward the future and to do so not only in the form of purposiveness, but also of expectation, anticipation, anxiety, and hope. Past, present and future are dimensions of the active self's time-fullness. (p. 330)

Counselling takes cognisance that the counsellor is not to prescribe, but to point to the future in view of the new narrative of the counsellor. The counsellor plays a specific role that involves 'not knowing' and not determining. The narrative of the counsellee is acknowledged as the transforming moment. The counsellor merely points out the potential and moments of change. In his early paradigm of narrative therapy, Müller pointed out five tasks of the caregiver. The tasks are to help the counsellee to tell their present story about their current crisis; guide the counsellee to tell the story of the past; assist with the understanding of the future; provide scope for the past and present stories to create a new story of positivity and, through imagination, construct a new story for the future (Müller 1998:331-332).

The counsellee takes responsibility for his or her own life and healing. Whereas Ganzevoort refers to negotiation of new meaning making of the story of the counsellee, Müller places the emphasis on the positioning of the counsellor as not knowing and engaging in conversational style communication and 'responsive-active listening'. The power lies with the counsellor to bring change instead of the counsellee initiating and sustaining change. In this narrative therapy approach, the dependency and vulnerability of the counsellee is dependent on the self-positioning of the counsellor. This raises the important issue of the power relations between counsellor and counsellee.

A third significant consideration is the awareness of God within the pastoral care process. Müller gives a more prominent and deliberate position for God than Ganzevoort. While Ganzevoort speaks in sociological terms about the sacred, Müller uses theological terms for God. God's story acts as the meta-narrative that rewrites the story of the counsellee in a more restoring present. Müller's opinion (1998) is:

With the help of God's story, we can reinterpret our own narratives. The reframing of an otherwise painful past story can become a stepping stone upon which counselees create a more favourable story. (p. 332)

Language and power of language is the fourth element in narrative therapy. Language is both the spoken and the written word. It is both literal and figurative, and includes the terms, concepts, words and sentences as well as the silent language of symbols, metaphors, gestures, habits and customs. The language gives authenticity to their story, because it is a genuine and meaningful portrayal of the real experiences of the counsellee. Language is not fixed but dynamic. Müller (2011) illustrates this dynamism when he describes the transition of the modern world and asserts that:

The language that I used and am using in order to express this transition, also changed through the years. Going back to my own track, I discover an evolution of language in my own description of the new world, which unfolded in and around me. (p. 1)

\section{Postfoundational or transversal approach}

Whereas Ganzevoort's narrative approach is a shift from doctrinal and ideational approaches, Müller (2004:298) responds to the limitations of the postmodern approaches of relativism, structuralism and constructionism's idea of 'the subjective, individualistic, and intra-psychic ideas on the construction of realities'. The social construction of reality (for Ganzevoort: lived experience) becomes the lens of pastoral care.

Müller claims that while hermeneutics has a role to play in pastoral care processes, the postfoundationalist approach goes beyond interpretation. This approach takes the situation - the actual reality context - more seriously than abstract interpretation. The following are imperatives of postfoundationalism:

- Concerns are real and about real people in concrete situations.

- A not knowing approach that leaves room for active engagement.

- A deep commitment to the actual context as well as traditions of interpretation.

- A consciousness that people are socially constructed within a self-realising reality.

- A broad reflective process that crosses boundaries, traditions, and contexts.

- An interdisciplinary approach.

Like Ganzevoort who seeks to relate experience (praxis) with reason, Müller follows in the footsteps of practical theologians such a Tracy and Migliore who relate the practical aspects of practical theology with the theories that provide the framework for pastoral care. The correlation between practice and theory has taken different shapes - from the influence of one over the other, to a more nuanced approach of keeping an engaged distance from each other.

Müller keeps the tension between socially constructed identity and rationality. Of identity and rationality, Müller (2004) claims that:

The moment when we realise and accept the fact that identity, and therefore rationality, is socially constructed as part of a continuing process, we are liberated from the urge to defend theological rationality over and against other so-called scientific rationalities. Then we also realise that our understanding of reality (rationality) is a co-product of a broader community and not the idiosyncratic product of theologians with their own isolated rationality. (p. 300) 
Rationality is not abstract reason or practical reason, but transversal reason. Müller (2011), influenced by Van Hasten, claims that the latter:

$[W]$ rites that transversal reasoning is not about arbitrarily opening up or closing ourselves off of other viewpoints, but rather it is about what it means to discover an epistemic space that allows for the king of interdisciplinary critical evaluation that includes a critical self-evaluation and optimal understanding. (p. 4)

The moment when this kind of reasoning takes place, is referred to as the 'edge effect'. According to Müller (2011:4), it is that moment or space where boundaries are blurred or where the shadows of boundaries meet to form flexibility 'intellectual and emotional flexibility'.

Müller (2004:294) is sceptical about hermeneutics on the basis that the hermeneutical approach to practical theology is inadequate because of the different language that was used, and the hermeneutical approach was unable 'to provide practical theology with real contextual outcomes'. The researcher can depend on three tools, which is telling the story, listening to the story and retelling the story for new landscape of imaginative understanding. This is always done with the co-researchers (Müller 2017:87).

Müller makes considerable contributions to pastoral care within intercultural contexts. He contributes to the shift towards experience. Experiences do not refer to generalisations about experience, but concrete, actual experiences. Experience is also embedded in the agency of the 'co-researchers' (Dreyer 2014:7). There is a shift from the counsellor as the all-knowing expert to the counsellee's narrative as the starting point of the pastoral care process towards seeing the hope in the story of God.

The narrative of the counsellee has a point of reference, which is beyond the limited abstract knowledge of theories and procedures. Within a multidisciplinary approach of reason, the boundaries of pastoral care intertwine with that of other sciences, adding to the knowledge of the counsellor and opening avenues for the counsellee to take responsibility for their story as a healing mechanism. Knowledge that is embedded in experience, takes a high ethical form - both how it is collected and how it is valued.

\section{Anthropology and open-ended narrative: An approach to human being}

My own employment of stories started in 2008 when I published my doctoral dissertation entitled, 'The interplay between the Christian story and the public story: In search of commonalities for moral formation under democratic rule' (Klaasen 2008). Since then, there has been a progression to practical theology and pastoral care. For the next two decades, I constructed a paradigm of narrative theology and pastoral care that I called 'open-ended narrative'. The marks of this paradigm are reason, particularity, history and community. Influenced by Browning, I too realised that experience is missing from my paradigm. During 2015 and 2016, I gave more attention to the form and structure of narrative and concluded that open-ended narrative is about critical engagement of the counsellee with the counsellor and God, in a triad relationship. My latest research led me to concentrate on the debate between experience and reasoning (Klaasen 2017).

To do effective pastoral care within intercultural societies, such as post-apartheid South Africa, three significant markers are imperative. The anthropological question of what it means to be human is significant for both the understanding of someone's story and the role that stories play in healing. Ganzevoort and Müller refer to humanity as an individual whose experience makes sense for him- and herself, and the person's interconnectedness with God, respectively. Both perspectives are insightful and plausible, but none of them explain the nature of being human. Within the realm of pastoral care in intercultural communities, the relationship between humans, and between humans and non-living beings, and humans and God is important. Within theological anthropology, human beings are created in the image of God. Within Christian historical development, the nature of creation is based on the mutually enriching, interdependent nature of the trinity. Formulated by the Cappadocians Fathers (Basil the Great; Bishop of Caesarea 329-379; Gregory of Nyssa 335-394, and Gregory of Nazianzus 329-390) and John of Damascus' use of perichoresis, the interaction of the Persons of the Trinity is the theological foundation of Christian anthropology (Klaasen 2013:186-187). Louw (2012) asserts:

The basic presupposition is that the manner in which we view human beings will determine how we treat human beings. One can argue that anthropology provides the paradigms ... that determine the attitudes of people (habitus)and their position within the realm of human relationships. (p. 4)

Drawing the distinction between psychology's anthropological presupposition that the human being is an autonomous independent being and pastoral care's anthropological presupposition that human beings have been created by God and are dependent on God, Louw (2000:249) opens up the potential for healing within an external source.

The anthropological presupposition that human beings are relational, addresses the imbalance of power that Ganzevoort attributes to agency, and Müller to the positioning of the counsellee in relation to the counsellor. Both Ganzevoort and Müller failed to challenge the imbalance of power of the story of the marginalised and that of the powerful society, culture or community (including parents and family). The story of the counsellee levels the power relation between counsellor and counsellee, because the story is presented as a gift to the counsellor, and the counsellee extends an invitation for the counsellor to enters the story. This approach of pastoral 
care is evident in the works of the Brazilian philosopher of education, Paulo Freire (1972a; 1972b) as quoted by Lartey (2004):

$[P]$ astoral caregivers who work with an empowerment model seek to assist in the 'conscientization' of the oppressed and marginalized through enabling them to ask questions about their life situation. Conscientization is a process within which people become aware of their situation and of the resources they possess to respond to and change things. (p. 58-59)

McClure (2012:272-273) rightly observes that '... modern caregivers help create opportunities for reflection, for deeper awareness of self and others'.

Postmodern pastoral care shifted from isolated, abstract and private doctrines and ideals to the centrality of experience. Ganzevoort shifts his pastoral care approach towards the interpreted experience, embodied experience and lived experience. It is the observables - tangibles of experience - that is interpreted for change and sense making. Müller, on the other hand, refers to the social constructionism of experience, and how and where the experience is situated. He refers to contextuality as the locus of experience. In both cases, the experience can be measured by scientific means. The change is usually determined by the impact of the counsellee.

Narrated experience is personal, because it is the personal story of the person in need of healing. The story is told in a personal form and manner that first and foremost makes sense to the storyteller. This kind of experience is powerful and transformative. The symbols, gestures, metaphors, words and phrases used to construct the plot have meaning for the counsellor to the extent that the counsellee chooses to tell and give meaning to the experience.

Narrated experience is lived and actual, although it is not limited to scientific measurables. Narrated experience is open to symbolic and metaphorical meaning. In this sense experience is also spiritual and sacred. The Christian story serves as a meta-narrative within which the story of the counsellee is placed. The Christian story is about the birth, ministry, death and resurrection of Jesus Christ. This story becomes re-enacted in the Eucharist. It is a story of hope, and every time persons partake in this story, their story is weaved in the story of Jesus Christ. Pastoral care presumes that God is active and known through self-disclosure. Pastoral counsellors and counsellees converge with the narrative of God and form a triad of experience. It is within the triad of narratives that healing takes place. Lartey (2006:17) observes that 'God is an active, loving and caring presence, discernible by human persons in the world, both in history and today.' Tangible experience is more than lived experience or socially constructed experience.

\section{Conclusion}

Intercultural communities are growing at an alarming pace. Congregations and other forms of communities learn from each other and make sense of the different rituals, symbols, metaphors and customs. These types of communities need a different kind of pastoral care than paradigms of care for monocultural communities. Narrative pastoral care does not only address the limitations of modern and postmodern forms of pastoral care, but narrative pastoral also keeps the tension between experience and reason, counsellee and counsellor, the dominant narratives of culture and society, and the personal narrative of the cared for. The Christian narrative provides a space of convergence for different narratives to interact, connect and disconnect. The Christian narrative provides both sense-making of the pain, distorted relations and separation of the counsellee as well as a sense of transformation, newness and healing through hope in the future. The basis for pastoral care is the open-endedness of narrative (like the Christian narrative) experience interaction is a triad of counsellee, counsellor and God.

\section{Acknowledgements Competing interests}

The author declares that no competing interest exists.

\section{Author's contributions}

I declare that I am the sole author of this research article.

\section{Ethical consideration}

This article followed all ethical standards for carrying out research without direct contact with human or animal subjects.

\section{Funding information}

This research received no specific grant from any funding agency in the public, commercial, or not-for-profit sectors.

\section{Data availability statement}

Data sharing is not applicable to this article as no new data were created or analysed in this study.

\section{Disclaimer}

The views and opinions expressed in this article are those of the authors and do not necessarily reflect the official policy or position of any affiliated agency of the authors.

\section{References}

Acolatse, E.E., 2014, For freedom or bondage: A critique of African pastoral practices, Springer, Boston, MA.

Barcelos, C.A. \& Gubrium, A.C., 2014, 'Reproducing stories: Strategic narratives of teen pregnancy and motherhood', Social Problems 61(3), 466-481. https://doi. org/10.1525/sp.2014.12241

Cense, M., 2019, 'Navigating a bumpy road: Young people's negotiation of sexual agency in a normative landscape', PhD thesis, Faculty of Religion and Theology, Vrije Universiteit Amsterdam.

Cense, M. \& Ganzevoort, R.R., 2017, 'Navigating identities: Subtle and public agency of bicultural gay youth', Journal of Homosexuality 64(5), 654-670. https://doi.org/ 10.1080/00918369.2016.1196992

Cense, M. \& Ganzevoort, R.R., 2018, 'The storyscapes of teenage pregnancy: On orality, embodiment, and narrative agency', Journal of Youth Studies 22(4), 568-583. https://doi.org/10.1080/13676261.2018.1526373 
Dreyer, J., 2014, 'The narrative turn in practical theology: A discussion of Julian Müller's narrative approach', Verbum et Ecclesia 35(2), 1-9. https://doi.org/ Muller's narrative appro.

Frank, A., 2000, 'The standpoint of storyteller', Qualitative Health Research 10, 354-365.

Freire, P., 1972a, Cultural action for freedom, Penguin, Harmondsworth.

Freire, P., 1972b, Pedagogy of the oppressed, transl. M.B. Ramos, Sheed \& Ward, London.

Ganzevoort, R.R., 1993, 'Investigating life-stories: Personal narrative in pastora psychology', Journal of Psychology and Theology 21(4), 277-287. https://doi.org/ 10.1177/009164719302100401

Ganzevoort, R.R., 2017, 'Naviguer dans les récits: Négociation des histoires canoniques dans la construction de l'identité religieuse', in P.Y. Brandt, P. Jesus \& P. Roman (eds.), Récit de soi et Narrativité dans la Construction de l'identité religieuse, pp. 45-62, Editions des Archives contenporaines, Paris.

Ganzevoort, R.R. \& Falkenburg, N., 2012, 'Stories beyond life and death: Spiritual experiences of continuity and discontinuity among parents who lose a child', Journal of Empirical Theology 25(2), 189-204. https://doi.org/10.1163/1570925612341249

Keesee, N.J., Currier, J.M., Neimeyer, R.A., 2008, 'Predictors of grief following the death of one's child: The contribution of finding meaning', Journal of Clinical Psychology 64(10), 1145-1163.

Klaasen, J., 2008, 'The interplay between the Christian story and the public story: In search of commonalities for moral formation under democratic rule', PhD thesis, Dept. of Theology, Stellenbosch University, Stellenbosch.

Klaasen, J.S., 2013, 'The interplay between theology and development: How theology can be related to development in post-modern society', Missionalia 41(2), 181-194. https://doi.org/10.7832/41-2-13

Klaasen, J.S., 2017, 'Practical theology and narrative: Contours and markers', Stellenbosch Theology Journal 3(2), 562-575. https://doi.org/10.17570/stj.2017. v3n2.a21

Klaasen, J., 2018a, 'Pastoral care in communities under transition: Interplay between care and culture', In die Skriflig/In Luce Verbi 52(1), 1-8. https://doi.org/10.4102/ ids.v52i1.2332
Klaasen, J., 2018b, 'Intersection of personhood and culture: A narrative approach of pastoral care to gender based violence', Scriptura 117(1), 1-11. https://doi. org/10.7833/117-1-1348

Lartey, E.Y., 1994, In living color: An intercultural approach to pastoral care and counselling, Jessica Kingsley, London.

Lartey, E.Y., 2006, Pastoral theology in an intercultural world, Wipf \& Stock, Eugene, OR.

Louw, D.J., 2000, A pastoral hermeneutics of care and encounter, Lux Verbi.BM, Stellenbosch.

Louw, D.J., 2012, 'A theological model for pastoral anthropology within the dynamics of interculturality: Cura animarum and the quest for wholeness in a colo-spirituality', In die Skriflig/In Luce Verbi 46(2), 1-9. https://doi.org/10.4102/ids.v46i2.57

McClure, B., 2012, 'Pastoral care', in B.J. Miller-Mclemore (ed.), The Whiley-Blackwell companion practical theology, pp. 269-278, Whiley-Blackwell, West Sussex.

Müller, J., 1998, 'Intercultural pastoral care and counselling: Resources from narrative therapy and brief pastoral counselling', Skrif en Werk 19(2), 325-341. https://doi. org/10.4102/ve.v19i2.592

Müller, J., 2004, 'HIV/AIDS: Narrative practical theology, and postfoundationalism: The emergence of a new story', HTS Teologiese Studies/Theological Studies 60(1 \& 2), 293-301. https://doi.org/10.4102/hts.v60i1/2.516

Müller, J., 2011, 'Postfoundational practical theology for a time of transition', HTS Teologiese Studies/Theological Studies 67(1), 1-5. https://doi.org/10.4102/hts. v67i1.837

Müller, J.C., 2017, 'African postfoundational practical theology', Acta Theologica 37(1), 86-96. https://doi.org/10.18820/23099089/actat.v37i1.6

Neimeyer, R.A., Baldwin, S.A. \& Gillies, J., 2006, 'Continuing bods and reconstructing meaning: mitigating complications in bereavement", Death Studies 30, 715-738.

Riley, T. \& Hawe, P., 2005, 'Researching practice: The methodological case for narrative inquiry', Health Education Research: Theory and Practice 20(2), 226-236. https:// doi.org/10.1093/her/cyg122

Wheeler, I., 2001, 'Parental bereavement: The crisis of meaning', Death Studies 25, 51-66. 